\title{
Public Management System Transformation in the Conditions of Digitalization
}

\author{
Olga Kvashina*, Irina Vinokhodova, Olga Belskya, Svetlana Fadeeva, and Olga \\ Kudryavtseva \\ Velikie Luki State Agricultural Academy, 182112 Velikie Luki, Russia
}

\begin{abstract}
In modern life conditions, within the framework of the "Digital Society" system formation, advanced functions of public administration are implemented as a key factor in the of efficiency improvement of all economic structures of Russian society. The key element of electronic interaction in public administration is the authorities supporting the working progress of the Plenipotentiary of the Russian Federation President at the federal district level. This allows to consider a system of digital generalization of providing public services to the people on the basis of the electronic information interaction between all its participants.
\end{abstract}

\section{Introduction}

The history of the public management system development can be correlated with the nature of formation principles and scientific theories of the public management and the application of key management theories in administration of economic processes on a particular territory. It appears if one considers the presidency in the US, which is expressed in the political and economic views of US President W. Wilson, who introduced the concept of "public management" into the scientific circulation and practical application [1] as a set of special administrative actions of the state structures on the processes taking place in society. W. Wilson formulated the basic principles of such management.

The first is the division according to various features and areas of influence on socioeconomic processes of a political and administrative nature [2]. The second is the identification and comprehensive accounting of distinctive features between government agencies and business organizations in order to develop and further implement effective management impact in achieving a specific socioeconomic result [3].

In the XX century and further at the beginning of the XXI century, scientific ideas on innovative implementation of economic processes regulation in the establishment of public administration centers were formed. It should be noted several key concepts that ensure the order of development of the management theory and practice (table. 1).

Based on the concepts of public authorities and management organization indicated in table 1, the most promising ideology is the "new public management", as within the framework of this innovative model of socioeconomic processes in certain territories were taken into account.

*Corresponding author: kva2106@mail.ru 
Table 1. Scientific concepts of public management implementation [4]

\begin{tabular}{|c|c|l|}
\hline $\begin{array}{c}\text { Name of the } \\
\text { concept }\end{array}$ & $\begin{array}{c}\text { Main } \\
\text { representatives }\end{array}$ & \multicolumn{1}{|c|}{ Main content } \\
\hline $\begin{array}{c}\text { Classical theory of } \\
\text { "ideal bureaucracy" }\end{array}$ & M. Weber & $\begin{array}{l}\text { The activities of a rationally organized } \\
\text { bureaucracy, acting as an orderly process through } \\
\text { the activities of public authorities with a clear } \\
\text { definition of their powers }\end{array}$ \\
\hline $\begin{array}{c}\text { School of scientific } \\
\text { management }\end{array}$ & $\begin{array}{c}\text { F. Taylor, F. } \\
\text { Gilbert, L. } \\
\text { Gilbert, G. } \\
\text { Gantt, etc. }\end{array}$ & $\begin{array}{l}\text { Organization of public administration authorities } \\
\text { activities based on management, following the } \\
\text { example of economic structures. Scientific } \\
\text { justification of each stage of making and } \\
\text { executing management decisions. }\end{array}$ \\
\hline $\begin{array}{c}\text { New public } \\
\text { management }\end{array}$ & C. Hood & $\begin{array}{l}\text { The theory of "managerialism", i.e. the } \\
\text { application of technologies of corporate } \\
\text { governance with priority to the availability of } \\
\text { professional management skills }\end{array}$ \\
\hline $\begin{array}{c}\text { Postmodern public } \\
\text { management }\end{array}$ & J.-F. Lyotard & $\begin{array}{l}\text { Independent expression and implementation of } \\
\text { entrepreneurial initiatives when making key } \\
\text { management decisions based on advanced } \\
\text { information technologies }\end{array}$ \\
\hline $\begin{array}{l}\text { Global public } \\
\text { management }\end{array}$ & D. Messner & $\begin{array}{l}\text { Organization of public authorities taking into } \\
\text { account the specifics of modern public services } \\
\text { globalization }\end{array}$ \\
\hline
\end{tabular}

There are several special scientific approaches and theories that define aspects of public administration (Fig.1).

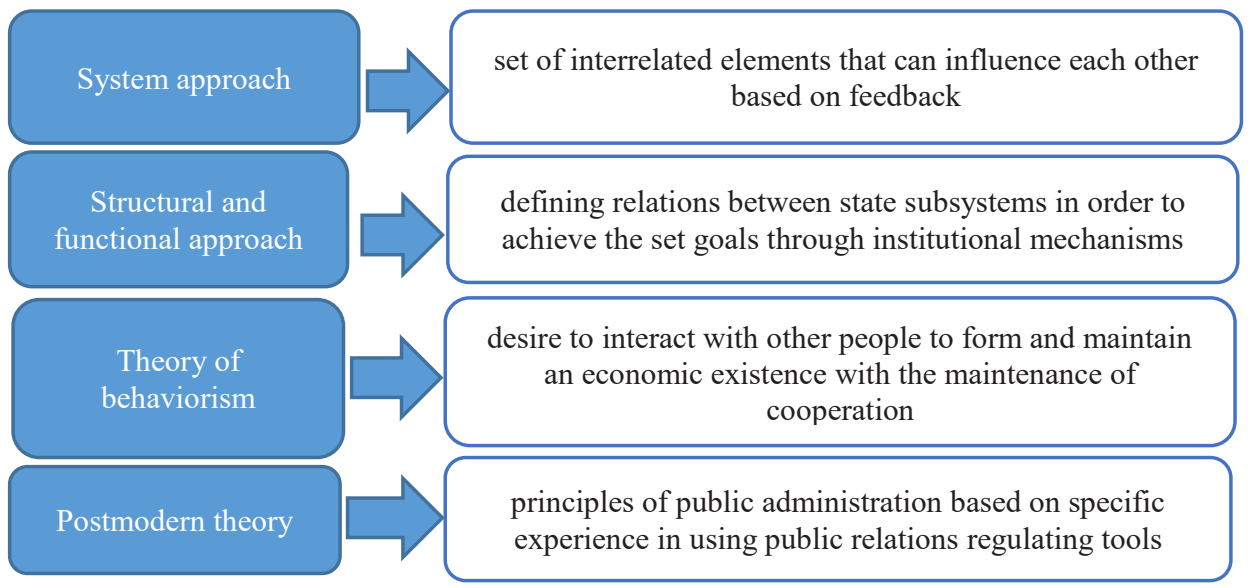

Fig.1. Main aspects of public management

The management process assumes the unity of two interrelated elements - the managing (subject) and the managed (object), which are complemented by the presence of goals and tools of the subject's influence on the object (Fig. 2).

Figure 2 shows the close partnership of management participants, which is reflected in the reliance on modern digital platforms using effective means of obtaining and processing multi-directional information. These digital information platforms and technologies support management interaction between the state and municipal authorities of socioeconomic processes regulation.

Thus, the system of public management is an ordered set of federal, regional and local authorities of socioeconomic regulation of certain economic processes, functioning through 
the use of modern information technologies in order to provide highly effective public services.

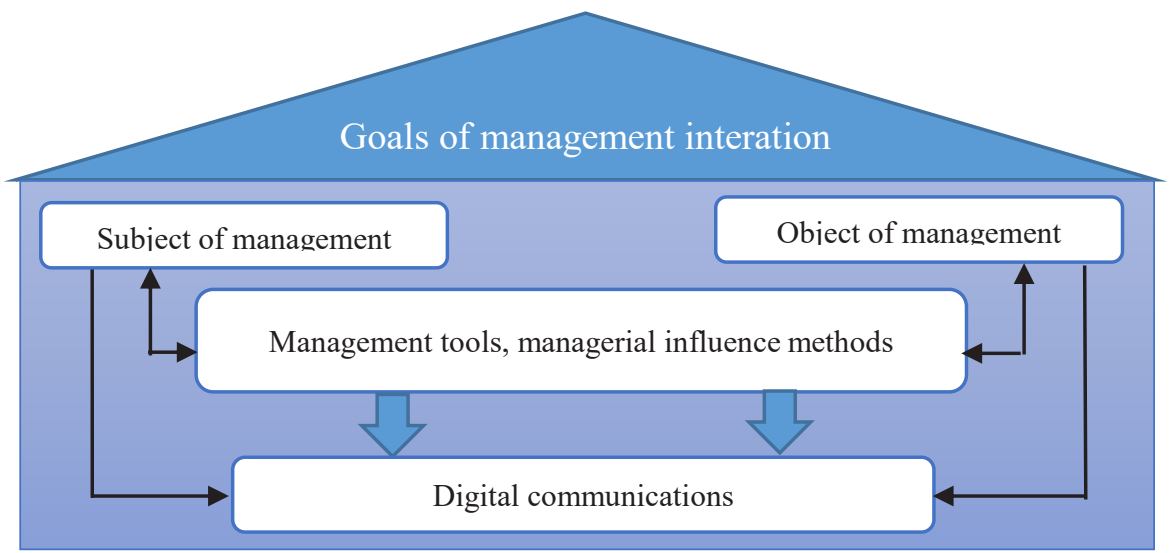

Fig. 2. Management interaction

\section{Materials and Methods}

The methodological basis of the present research are the scientific works of Russian and foreign experts in the field of theory of security and the functioning of public authorities, aspects of the digital economy in the Russian and foreign practice, information and resource support of state and municipal management, digital process support of public-private interaction. Methods of statistical and system analysis, methods of generalization, classification, system and structural-functional approaches were used in the research.

The scientific novelty of this research consists in the development of a system of functional and technological transformation of public management, based on the use of digital technologies in the conditions of the formation and expansion of information communications that are used by state and municipal administration authorities when interacting with the people, business structures in making decisions on the public services.

We believe that when summarizing the results obtained during the study, it is possible, firstly, to consider the quality of public administration in the context of digitalization as the quality degree of identifying, analyzing, evaluating and solving socioeconomic problems in the life of the people and the business community based on available resources and electronic technologies. Secondly, the sources of transformation of public management should include digital support; budget financing; legal regulation of digital use of information systems; special requirements for procurement procedures of goods and services in the field of information and communication technologies. Thirdly, a modern algorithm for digitalization of public administration authorities based on the results of the conditions analysis of formation and use of government information systems containing stages, at which it is mandatory to assess the effectiveness of the use of digital technologies from the public administration quality criteria point of view. Fourthly, the methodology for assessing the quality of functions and powers of public administration authorities in the conditions of digitalization should reflect the calculation of the electronic government (e-government) index and the electronic participation (e-participation) index, as well as a number of private indicators.

We also believe that the directions for further digital transformation of the public management system should include: 
- aspects of expanding the use of unified electronic portals of public authorities, that ensure the establishment of direct links on the provision of public services;

- possible simplification of the use of information technologies thanks to the development of mobile means of information transmission and processing;

- a general list of digital products within the framework of providing public services with the possibility of an accelerated search for the required product;

- creation of experimental sites and test zones for the introduction of digital technologies in electronic administration.

\section{Results and Discussion}

Features of the development of socioeconomic processes in society determine the formation and development of qualitatively new forms of obtaining, analyzing, moving and using of the information resources as one of the key means of systemic economic development. In this regard, new requirements are being formed for the processing and application of multidimensional information data, reflecting the increasing range of innovative transformations issues and maintaining the stable functioning of state and municipal authorities. A number of direct factors in the formation and further development of digitalization of management and public-private relationships can be compared and considered by SWOT analysis (table 2).

Table 2. SWOT analysis of the use of digital technologies in public administration

\begin{tabular}{|c|c|}
\hline Strengths & Weaknesses \\
\hline $\begin{array}{l}\text { 1. Optimal assessment and striving to counter } \\
\text { foreign policy challenges and increase the } \\
\text { level of the economy digitalization } \\
\text { 2. Increasing the level of efficiency of } \\
\text { economic resources for subjects of } \\
\text { digitalization } \\
\text { 3. Improving the effectiveness of electronic } \\
\text { information communications in the structure } \\
\text { of public-private partnership } \\
\text { 4. Increasing the number of users of Internet } \\
\text { resources } \\
\text { 5. Improving the level of information and } \\
\text { communication efficiency of government } \\
\text { websites }\end{array}$ & $\begin{array}{l}\text { 1. Technological failures, loss or distortion of } \\
\text { information used on the basis of electronic } \\
\text { technologies } \\
\text { 2. Inefficiency of the information process } \\
\text { management system } \\
\text { 3. Inefficient coordination of financial } \\
\text { resource allocation in the development of } \\
\text { digitalization } \\
\text { 4. Insufficiency in state and municipal } \\
\text { support for small and medium-sized business } \\
\text { initiatives } \\
\text { 5. Lack of clearly structured tactics for the } \\
\text { implementation of digitalization in various } \\
\text { areas of providing public goods }\end{array}$ \\
\hline Opportunities & Threats \\
\hline $\begin{array}{l}\text { 1. Support of digitalization from the } \\
\text { government } \\
\text { 2. Development of e-commerce and } \\
\text { provision of public goods } \\
\text { 3. Basis for the development of cooperation } \\
\text { between public and administrative structural } \\
\text { units with private businesses } \\
\text { 4. Legal regulation of the processes of } \\
\text { digitalization of public administration and } \\
\text { economy } \\
\text { 5. Development of the education system and } \\
\text { professional training and retraining of } \\
\text { specialists in the digitalization field }\end{array}$ & $\begin{array}{l}\text { 1. Insufficient funding for digital technology } \\
\text { development } \\
\text { 2. Relative reliability and efficiency of digital } \\
\text { forms of interaction between public } \\
\text { authorities and the people in the provision of } \\
\text { public services } \\
\text { 3. Inconsistency between theoretical } \\
\text { scientific developments in the digitalization } \\
\text { field and their practical development } \\
\text { 4. Insufficient level of cybersecurity and } \\
\text { protection of personal data and documents } \\
\text { from criminal use threats } \\
\text { 5. Low level of infrastructure for maintaining } \\
\text { digital interaction }\end{array}$ \\
\hline
\end{tabular}


The factors shown in table 2 indicate a high level of threats and shortcomings in the process of the public administration system modern transformation in the Russian Federation. This is largely reflected in the digitalization of management relationships and the strengthening of horizontal partnerships between the state and municipal authorities, the people and private businesses [5]. At the same time, a number of opportunities and advantages are seen in the development and use of digital elements for the provision of private and public economic services, while removing unnecessary organizational and management barriers.

Considering the electronic procedure for providing public management services, it should be emphasized that in this case it is necessary to coordinate different actions in the system of using information and communication technologies. They must provide public services that meet the quality standards of public needs and the time parameters of interaction with the people.

Effective provision of such services in the e-administration system can be ensured by implementing appropriate transformations such as the following:

- electronic and digital provision of information to users based on the use of modern digital technologies for collecting information by analyzing the situation in various areas of socioeconomic relations;

- provision of services through the use of property of various forms of ownership (depending on the nature of the partnership between the state and municipal authorities with each other and representatives of private businesses).

These transformations have already been implemented as part of the process of building the structure of "open government" provided for by the President of the Russian Federation Decree of February 8, 2012. This is associated with the implementation of a number of measures:

1. Functioning of special state authorities (for example, the Expert Council under the Chairman of the Russian Federation Government; "Open Government" Development Commission). This is aimed at systematizing partnerships with various public councils [6].

2. Development of productive electronic and technical components for accelerated consideration and execution of complaints, suggestions and messages from the people along with the generalization of various information data into clearly structured communications that allow taking into account the specifics of various socioeconomic problems at the territorial level of public management.

3. Modernization of information technology tools that determine the parameters and results of the "electronic budget" system, as well as electronic processing of information on efficiency of the use of provided financial resources, that are allocated within the framework of state support for digital transformations of public management decision-making processes.

4. Thus, the digitalization of public administration in the Russian Federation is implemented through the development and use of various information systems, which expand the ability to process large amounts of information in an accelerated mode. With a clear structural functioning of information systems, a single digital space where ensured systematic public-private cooperation is created.

When building an e-administration system, it is possible to refer to foreign experience in organizing the activities of state authorities in the system of electronic information registration, their interaction with the people and the private economy sector by means of the "e-government" structure (table 3).

The content of table 3 defines the variety of different activities in the process of forming a productive electronic administration, which uses a wide list of information sources. This is complemented by the need of technological improvement of the electronic infrastructure in 
building stable information contacts between the structural elements of state and municipal administration [7].

The criteria framework for evaluating the performance of public management allows to create a system of indicators for evaluating public management:

- efficiency, i.e. comparison of planned and actual indicators;

- cost-effectiveness;

- quality;

- the ratio of the amount of public services of the system (efficiency) and the cost of providing these services (cost-effectiveness) based on the use of digital means of processing source data;

- compliance with the expectations of the public administration structures staff;

- introduction of innovations (modern information and digital technologies for optimizing the activities of state and municipal employees).

Table 3. Foreign experience in using digital technologies in managing economic processes $[8,9]$

\begin{tabular}{|l|l|}
\hline State & Practical experience in using digital technologies \\
\hline Republic of & $\begin{array}{l}\text { Development of e-administration tools by: } \\
\text { - creating a unified system of state electronic services with their ongoing quality } \\
\text { improvement. } \\
\text { - using state electronic services as a basic component of the system, } \\
\text { - existing state automated information system (SAIS). }\end{array}$ \\
\hline Hungary & $\begin{array}{l}\text { Electronic and digital support of modernization processes in the provision of } \\
\text { public services for citizens and private organizations. } \\
\text { Expanding private enterprise participation in the distribution of professional } \\
\text { knowledge in the field of building an e-government system. }\end{array}$ \\
\hline Kazakhstan & $\begin{array}{l}\text { "Electronic state" system, formed through expanding the activities of state } \\
\text { management structures in the virtual space. } \\
\text { Expanding the forms of electronic document management and electronic } \\
\text { accounting of various data. }\end{array}$ \\
\hline Turkey & $\begin{array}{l}\text { Expansion of IT infrastructure and IT competence development programs made } \\
\text { for citizens and private enterprises in partnership with official authorities. } \\
\text { Public management support for attracting investment in the HR and IT sector } \\
\text { standards development. }\end{array}$ \\
\hline Chile & $\begin{array}{l}\text { Preparation of long-term public management system projects for development } \\
\text { of digital tools to make management decisions through legal regulation and } \\
\text { support digital networks creation to production and technological use, as well } \\
\text { as the modernization of technologies for collecting and analyzing information } \\
\text { resources }\end{array}$ \\
\hline
\end{tabular}

According to the highlighted performance achievement indicators listed above, evaluation approaches to the public management structure are:

- normative-legislative;

- expertive;

- economic;

- IT approach.

There are different indices, which can be defined as official management structures quality functioning indicators of functioning in the context of digitalization needed to maintain a high-quality level of life. These indices also serve as a public services representatives. The following indices can be listed:

1) e-government index (Ieg), i.e. the percentage of the population receiving state and municipal services in electronic form, among the population aged 15-72 years; 
2) index of electronic participation (Iep), i.e. the percentage of the population using internet resources among population aged 15-74 years;

3 ) the volume of investment in fixed assets $(\mathrm{Fa})$;

4) retail trade turnover $(R t t)$;

5) the level of per capita income of the population $(I L)$;

6) tax and non-tax revenues $(R t)$.

The level of quality of public administration authorities functioning can be calculated using the following formula:

$$
Q p f=I e g+I e p+F a+R t t+I L+R t
$$

The obtained calculations of the quality of public administration authorities functioning of the Russian Federation federal districts are presented in the table 4, which also combines the basic indicators for the Russian Federation subjects over the past five years.

Table 4. Summary of the indicators of the quality of public administration authorities functioning

\begin{tabular}{|c|c|c|c|c|c|c|c|c|}
\hline \multirow[b]{2}{*}{$\begin{array}{c}\text { Indicator } \\
\text { (mean } \\
\text { value) }\end{array}$} & \multicolumn{8}{|c|}{$\begin{array}{l}\text { Indicators of the quality of public administration authorities functioning in the } \\
\text { subjects of the Russian Federation }\end{array}$} \\
\hline & $\begin{array}{l}\text { Central } \\
\text { federal } \\
\text { district }\end{array}$ & $\begin{array}{l}\text { North- } \\
\text { West } \\
\text { federal } \\
\text { district }\end{array}$ & $\begin{array}{l}\text { South } \\
\text { federal } \\
\text { district }\end{array}$ & $\begin{array}{l}\text { North- } \\
\text { Caucasus } \\
\text { federal } \\
\text { district }\end{array}$ & $\begin{array}{l}\text { Volga } \\
\text { federal } \\
\text { district }\end{array}$ & $\begin{array}{l}\text { Ural } \\
\text { federal } \\
\text { district }\end{array}$ & $\begin{array}{c}\text { Siberian } \\
\text { federal } \\
\text { district }\end{array}$ & $\begin{array}{c}\text { Far- } \\
\text { Eastern } \\
\text { federal } \\
\text { district }\end{array}$ \\
\hline Ieg & 71,1 & 73,4 & 64,9 & 59.3 & 61,9 & 70,5 & 62,7 & 69,8 \\
\hline Iep & 82,2 & 84,2 & 80,6 & 81 & 78,1 & 82,6 & 78.4 & 81,3 \\
\hline $\mathrm{Fa}$ & 26,4 & 11,3 & 8,8 & 3,3 & 16,1 & 17,4 & 9,8 & 6,9 \\
\hline Rtt & 34,2 & 9,6 & 10,1 & 5,2 & 17,8 & 8,9 & 9,7 & 4,6 \\
\hline IL & 17,3 & 14,3 & 8,8 & 9,9 & 11,3 & 14,4 & 8,3 & 15,7 \\
\hline $\mathrm{Rt}$ & 36,4 & 11,8 & 6,3 & 1,9 & 14,6 & 11,9 & 10,2 & 6,9 \\
\hline Total & 267,6 & 204,6 & 179,4 & 101,4 & 199,7 & 205,6 & 100,7 & 185,3 \\
\hline
\end{tabular}

It is obvious that the closer the federal district is to the cities of federal significance, the higher the quality of public administration authorities functioning. In our opinion, the digital model of public management might be successful if digital management is controlled by the state, and the distribution of services via the internet becomes cheaper and easier, i.e. socalled getting a public service in one "click" [10].

\section{Conclusions}

1. The system of public management is an ordered set of socioeconomic structures of federal and territorial regulation of relevant economic processes that function through the extensive use of modern information technologies in order to provide services to the people and support small and medium-sized businesses.

2. The sources of digitalization of public management in the Russian Federation are various factors of a technological, organizational and informational nature, that determine the process of effective electronic communications forming when using digital technologies in the development of advanced means and methods of electronic interaction between citizens and organizations in certain territories.

3. The main criteria for the quality of public management are: technological support of public-private partnership in providing support for private enterprise projects aimed at increasing the level of goods production and providing services to citizens; the effectiveness of the digital procedure for providing public services related to obtaining services demanded by the people based on sustainable information communications; optimal distribution of functions and powers between public administration authorities, taking into account the 
coordination of their actions in the provision of public services; ensuring the participation of the population and private businesses in public management processes based on digital technologies.

4. We believe that a model of the public management system transformation should be applied at the state level. This model consists in determining the digital transition of the public management system to the e-administration structure based on the functional and communication transformations of interaction between the state and municipal authorities with the people and the business community.

\section{References}

1. S. Shane, Handbook of Technology and Innovation Management (2008)

2. A. G. Barabashev, E. L. Guseletova, Issues of state and municipal management, 2, 66 (2010)

3. V. E. Chirkin, Russian J. of Comparative Law., 76, 2(3) (2015)

4. S. I.Vershinina, Juridical Sciences, 10, 1 (2010)

5. E. Kabbar, P. Dell Weaknesses of the E-Government Development Index (IT Enabled Services), 111 (2014)

6. N. I. Morozova, Regional economy: theory and practice, 53, 32 (2011)

7. C. W. Anderson, Comp. Pol., 4-1, 117 (1971)

8. Y. V. Vertakova, M. A. Plakhotnikova, A. V. Babkin, Innovative clusters of the digital economy: theory and practice, 295 (2018)

9. M. Islami, Masyarakat Telematika Dan Informasi: Jurnal Penelitian Teknologi Informasi dan Komunikasi, 8, 137 (2018)

10. Decree of the President of the Russian Federation «On the working group on the preparation of proposals for the formation of the Open Government system in the Russian Federation», ATP Consultant Plus, 150 (02.02.2012) 